\title{
Síndrome de Eissenmenger y gammagrafía de perfusión pulmonar
}

\section{Eisenmenger's syndrome and lung perfusion scintigraphy}

\author{
Víctor Andrés Marín-Oyaga ${ }^{\mathrm{a}, *}$, Arturo Mejía-López ${ }^{\mathrm{a}}$ y Gerardo Cortés-Germán ${ }^{\mathrm{b}}$ \\ a Servicio de Medicina Nuclear, Fundación Cardioinfantil-Instituto de Cardiología, Bogotá, Colombia \\ ${ }^{\mathrm{b}}$ Facultad de Medicina, Fundación Universitaria Sanitas, Bogotá, Colombia
}

\section{PALABRAS CLAVE \\ Pulmón; \\ Gammagrafía; \\ Cortocircuito; \\ Comunicación interauricular}

\section{KEYWORDS}

Lung;

Scintigraphy;

Shunt;

Atrial septal scintigraphy

\section{Caso}

Mujer de 26 años que presentó episodio sincopal y disnea aguda. Tenía antecedentes de comunicación interauricular con hipertensión pulmonar diagnosticados cuatro años atrás. El ecocardiograma reportó hipertrofia y dilatación de cavidades derechas, insuficiencia tricuspidea e hipertensión

\footnotetext{
* Autor para correspondencia.

Correo electrónico: vmarin@cardioinfantil.org
} (V.A. Marín-Oyaga). pulmonar severa y reducción del tamaño de las cavidades izquierdas. No se hizo referencia al cortocircuito conocido.

Se realizó gammagrafía de perfusión pulmonar (GPP) por diagnóstico de hipertensión pulmonar y sospecha de tromboembolia pulmonar con $5 \mathrm{mCi}(185 \mathrm{MBq})$ de ${ }^{99 m}$ Tc-Macroagregados-de-albúmina por vía intravenosa. Se adquirieron imágenes estáticas torácicas y por los hallazgos se adicionaron imágenes al cráneo. El estudio fue negativo para tromboembolia pulmonar pero llamó la atención la captación anormal del radiotrazador en el ventrículo izquierdo (hallazgo extremamente inusual), encéfalo, tiroides y riñones indicativo de cortocircuito cardiaco de derecha a izquierda (C-D-I) (fig. 1). Se comparó con un estudio realizado dos años atrás y se halló progresión actual del cortocircuito (fig. 2).

Se diagnosticó síndrome de Eissenmenger. Dado que se descartó tromboembolia pulmonar y por el aumento de cortocircuito, se consideró candidata a trasplante cardiaco.

\section{Discusión}

Este síndrome representa la forma más avanzada de hipertensión pulmonar asociada con cardiopatía congénita ${ }^{1}$. La coexistencia de tromboembolia pulmonar es del $20 \%$, de ahí que sea importante descartarla; ocurre por cambios estructurales y funcionales endoteliales secundarios. El hallazgo de captación cerebral y renal en una GPP es indicativo de C-D-I2. Como conclusión se puede señalar que la GPP es una excelente alternativa diagnóstica no invasiva para descartar 
A

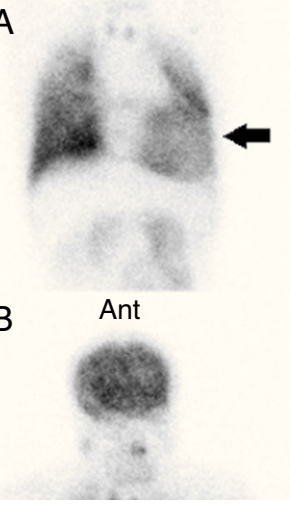

Figura 1

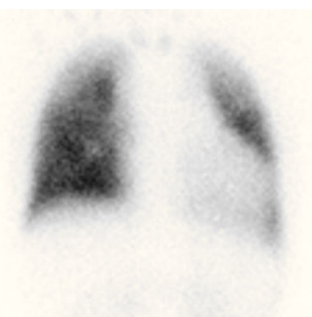

Ant
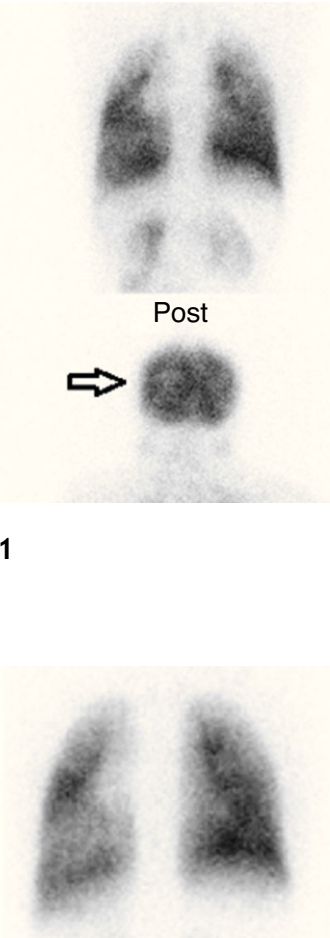

tromboembolia pulmonar, detectar simultáneamente C-D-ו y evaluar su evolución durante el seguimiento ${ }^{3}$.

\section{Reconocimientos y agradecimientos}

A la doctora Eliana Calderón Pacheco por su fundamental contribución, y a los doctores Claudia Gutiérrez Villamil y José Sinay Arévalo Leal, por su constante apoyo y orientación.

\section{Conflicto de intereses}

Los autores declaran no tener conflicto de intereses.

\section{Bibliografía}

1. Beghetti M, Galiè N. Eisenmenger syndrome. JJ Am Coll Cardiol. 2009; $73: 3-40$

2. Goshen E, Oksman Y, Rotenberg G, Zwas ST. Absent pulmonary uptake on 99mTc MAA perfusion lung scan due to severe right-toleft shunt. Semin Nucl Med. 2004;15:7-8.

3. Caobelli F, Paghera B, Panarotto MB, Terzi A, Rodella C, Biasiotto $G$, et al. 99mTc-MAA lung scan can be an alternative in detection and follow-up of patent foramen ovale. Int J Cardiol. 2011;29:6-8.

Figura 2 